\section{Detection and characterisation of NAD(P)H-diaphorase activity in Dictyostelium discoideum cells (Protozoa)}

\author{
A. Amaroli, M.G. Chessa \\ Department of Earth Sciences, \\ Environment and Life, University \\ of Genova, Italy
}

\begin{abstract}
In Dictyostelium discoideum (D. discoideum), compounds generating nitric oxide (NO) inhibit its aggregation and differentiation without altering cyclic guanosine monophosphate (cGMP) production. They do it by preventing initiation of cyclic adenosine monophosphate (cAMP) pulses. Furthermore, these compounds stimulate adenosine diphosphate (ADP)-ribosylation of a $41 \mathrm{kDa}$ cytosolic protein and regulate the glyceraldehyde-3phospate dehydrogenase activity. Yet, although $D$. discoideum cells produce NO at a relatively constant rate at the onset of their developmental cycle, there is still no evidence of the presence of nitric oxide synthase (NOS) enzymes. In this work, we detect the nicotinamide adenine dinucleotide phosphate-diaphorase (NADPH-d) activity in $D$. discoideum and we characterise it by specific inhibitors and physical-chemical conditions that allegedly distinguish between NOS-related and -unrelated NADPH-d activity.
\end{abstract}

\section{Introduction}

In his paper entitled Chemical messengers development: a hypothesis, McMahon ${ }^{1}$ postulated how simple derivatives of metabolites including the small molecules of classical neurotransmitters and cyclic nucleotides - were employed as regulatory molecules throughout the eukaryote evolution. From this perspective, the author assumed that their role evolve: from being intracellular messengers they evolve into intercellular messengers for the relatively slow cell-cell communication between singlecell eukaryotes and for the related development of intercellular messages. This hypothesis has been supported by the detection and characterisation of molecules correlated to neurotransmitters in non-nervous tissues and systems, such as: non-neuromuscular cells and gametes, ${ }^{2-8}$ animal embryos, ${ }^{9-15}$ coelenterates $^{16}$, plants ${ }^{17,18}$ and, most of all, protozoa. ${ }^{19-31}$

The identification of neurotransmitters in protozoa, later termed the pre-nerve transmitter system by Buznikov, ${ }^{8}$ indicates that these signal molecules are acquired in early evolution before the appearance of the nervous system, as they are already present in, or synthesised by, protozoa. Among neurotransmitters, nitric oxide (NO) is known to be a ubiquitous biological messenger molecule that may play a role in neurotransmitter release, neural development, synaptic plasticity, and the regulation of gene expression. Furthermore, excessive production of NO is neurotoxic and is implicated in a variety of neurological disorders. ${ }^{32} \mathrm{NO}$ is a very unstable molecule synthesised by the nitric oxide synthase (NOS) enzyme that catalyses the conversion of L-arginine to citrulline and $\mathrm{NO} .^{33,34}$

The NOS enzyme can transfer electrons from co-substrate $\mathrm{NAD}(\mathrm{P}) \mathrm{H}$ to an electron acceptor substrate - a soluble tetrazolium salt - bringing about a coloured insoluble compound. ${ }^{35}$ For some years this NOS ability, known as nicotinamide adenine dinucleotide phosphate-diaphorase (NADPH-d) activity, has been considered as synonymous to NOS. ${ }^{36,37}$ This activity can also be produced by enzymes other than NOS. ${ }^{38-41}$ Among protozoa, NOS activity and NO production have been identified and characterised in Paramecium, ${ }^{25,26,42}$ Leishmania donovani, ${ }^{19}$ Physarum polycephalum, ${ }^{22}$ Trypanosoma cruzi,${ }^{21}$ as well as in Dictyostelium discoideum (D. discoideum). In these protozoa, NO-generating compounds: i) inhibit its aggregation and differentiation without altering cyclic guanosine monophosphate (cGMP) production ${ }^{43}$ by preventing initiation of cyclic adenosine monophosphate (cAMP) pulses; ${ }^{44}$ ii) stimulate adenosine diphosphate (ADP)-ribosylation of a $41 \mathrm{kDa}$ cytosolic protein; ${ }^{45,46}$ and iii) regulate the glyceraldehyde-3-phospate dehydrogenase activity. ${ }^{47}$ Although it has been demonstrated that cells in D. discoideum produce NO at a relatively constant rate at the onset of their developmental cycle, ${ }^{48}$ the presence of NOS enzymes has not been reported yet. In addition, although the whole $\boldsymbol{D}$. discoideum genome has been sequenced, there is no information about the presence of a coding region for NOS and only a putative NOS-interacting protein (dictyBase, gene ID: DDB_G0270882) has been deduced. In this work, we detect NADPH$\mathrm{d}$ activity in D. discoideum and we characterise it using specific inhibitors and physical-chemical conditions that supposedly distinguish between NOS-related and -unrelated NADPH-d activity. ${ }^{25,49,50}$
Correspondence: Dr. Andrea Amaroli, Department of Earth Sciences, Environment and Life (DISTAV), University of Genova, Corso Europa 26, 16132 Genova, Italy.

Tel. +39.010 .353 .8545 - Fax: +39.010 .3538209 .

E-mail: amaroli@dipteris.unige.it

Key words: NADPH-diaphorase activity, protozoa, nitric oxide synthase.

Conflict of interests: the authors declare no conflict of interests.

Received for publication: 2 March 2012.

Accepted for publication: 26 July 2012.

This work is licensed under a Creative Commons Attribution NonCommercial 3.0 License (CC BYNC 3.0).

(C) Copyright A. Amaroli and M.G. Chessa, 2012 Licensee PAGEPress, Italy

European Journal of Histochemistry 2012; 56:e47 doi:10.4081/ejh.2012.e47

\section{Materials and Methods}

\section{Cell reproduction and development}

The amoebae used in this work were axenically induced by inoculating the fruiting bodies in Falcon flasks (BD Biosciences, San Jose, CA, USA) containing AX-2 axenic medium and supplemented with tetracycline, as described in Amaroli et al. ${ }^{51}$ The fruiting bodies were induced by transferring some drops of the AX2 culture onto a Enterobacter aerogenes monolayer growing on a nutrient agar-N plate. ${ }^{24}$ The plates were incubated in a moist chamber for three days at $25^{\circ} \mathrm{C}^{52}$ to allow the cells to exhaust the supply of bacteria (i.e. to reach starving conditions) and migrate and aggregate. When the fruiting bodies had developed, the plates were kept at $4^{\circ} \mathrm{C}$.

\section{Experimental samples}

The experimental samples used in this study were taken as follows:

- the total sample (T-sample) was obtained by centrifuging a $30 \mathrm{~mL}$ sample of an AX-2 culture of logarithmically growing single-cell amoebae at $130 \mathrm{~g}$ for $10 \mathrm{~min}$.

- the total extract sample (TE-sample) was obtained by transferring the T-samples to $80^{\circ} \mathrm{C}$ for $10 \mathrm{~min}$. After protease inhibitors [2 $\mathrm{mM}$ phenylmethylsulfonyl fluoride (PMSF) and $5 \mu \mathrm{g} / \mathrm{mL}$ leupeptine] were added, the samples were homogenised in $0.3 \%$ Triton $\mathrm{X}-100$ and centrifuged at $1000 \mathrm{~g}$ for $30 \mathrm{~min}$. - the membrane sample (M-sample) (pellet) and the cytoplasm sample (C-sample) (supernatant) were obtained by centrifug- 
ing six T-samples frozen overnight at $-20^{\circ} \mathrm{C}$ and resuspended in $1000 \mu \mathrm{L}$ of $50 \mathrm{mM}$ tris(hydroxymethyl)aminomethane (Tris$\mathrm{HCl})$, pH 8.0 at $1000 \mathrm{~g}$ for $20 \mathrm{~min}$.

the membrane extract sample (ME-sample) - after protease inhibitors (2 mM PMSF, and $5 \mu \mathrm{g} / \mathrm{mL}$ leupeptine) were added - was obtained by homogenising the M-samples in $0.3 \%$ Triton X-100 and then by centrifuging at $1000 \mathrm{~g}$ for $30 \mathrm{~min}$.

\section{Non-denaturing electrophoresis}

To characterise electrophoretically NADPH-d activity, the total protein content of TE-samples was evaluated using the BioRad Assay Kit (Hercules, CA, USA), within factory specifications. A $30 \mathrm{mg}$ total protein extract was layered on $8 \%$ polyacrylamide gel. The molecules were electrophoretically separated for $2 \mathrm{~h}$ at $80 \mathrm{~V}$. Afterwards, the gels were removed and agitated for $15 \mathrm{~min}$ at $25^{\circ} \mathrm{C}$ in $50 \mathrm{mM}$ Tris-HCl, $\mathrm{pH}$ 7.4. A staining bath containing $0.35 \%$ Triton X-100 in $50 \mathrm{mM}$ Tris-HCl, pH 7.4, $0.25 \mathrm{mM}$ nitroblue tetrazolium (NBT), and $0.25 \mathrm{mM} \beta-\mathrm{NADPH}$ or $\beta$-NADH, was added to cover the gel for $1 \mathrm{~h}$ at $25^{\circ} \mathrm{C}$. Enzyme activity was blocked in the gels by replacing the reaction mixture with a solution of $10 \%$ methanol and $7.5 \%$ acetic acid in distilled water. ${ }^{25,53}$ We used ImageJ 1.33 software (NIH, Bethesda, MD, USA) to evaluate the optical density (OD) and the apparent molecular mass of the experimental samples bands.

\section{Immunoblot analysis}

In order to detect the presence of proteins immunocitochemically NOS-related, the total protein content of TE-samples was evaluated using the BioRad Assay Kit (Bio-Rad, Hercules, CA, USA), within factory specifications. A $30 \mu \mathrm{g}$ total protein extract was run in $8 \%$ sodium dodecyl sulfate polyacrylamide gel electrophoresis (SDS-PAGE) and then transferred to a nitrocellulose membrane. Non-specific binding sites were blocked with a blocking buffer containing Tris-buffered saline (pH 7.4) and $0.1 \%$ Tween- 20 with $3 \%$ non-fat milk powder for $45 \mathrm{~min}$ at $25^{\circ} \mathrm{C}$. The blot was incubated with a blocking buffer containing the anti-NOS universal (Sigma, N217), or brain (Sigma, N7155), or endothelial (Sigma, N3893) antibody produced in rabbit, diluted 1:500, overnight at $4^{\circ} \mathrm{C}$. After washing, the blot was incubated with an anti-rabbit immunoglobulin secondary antibody conjugated with alkaline phosphatase, diluted 1:500 for $3 \mathrm{~h}$ at $25^{\circ} \mathrm{C}$. After rinsing thoroughly, detection was performed directly on the membrane using the one-step NBT/5-Bromo-4-chloro-3-indolyl phosphate (BCIP) kit (Thermo Fisher Scientific Inc., Rockford, IL, USA) ${ }^{25}$ A $20 \mu \mathrm{g}$ total protein of mouse tissue extracts was used as a positive control for the NOS antibodies.
Histochemical evaluation of the nicotinamide adenine dinucleotide phosphate-diaphorase activity

Cells were fixed in $0.1 \mathrm{M}$ phosphate buffer (PB) $(\mathrm{pH} 7.4)$ by the presence of $2 \%$ paraformaldehyde (PFA). The fixed cells were transferred onto the slide and after air-drying they were incubated for $15 \mathrm{~min}$ at $37^{\circ} \mathrm{C}$ in 50 $\mathrm{mM}$ Tris-HCl (pH 7.4), and then for $45 \mathrm{~min}$ at $37^{\circ} \mathrm{C}$ in $1 \mathrm{mM} \beta$-NADPH or $\beta$-NADH co-substrate, $0.8 \mathrm{mM}$ NBT and $1 \%$ Triton X-100 in 50 $\mathrm{mM}$ Tris $\mathrm{HCl}$ (pH 7.4). The controls were performed omitting the co-substrates. ${ }^{25}$

\section{Standard reaction for spectropho- tometric evaluation of the} nicotinamide adenine dinucleotide phosphate-diaphorase activity

The evaluation of NADPH-d activity was performed as suggested by Kuonen et al., ${ }^{53}$ appropriately modified. Aliquots of TE-sample were placed in cuvettes containing $1.0 \mathrm{~mL}$ of reaction mixture $(50 \mathrm{mM}$ Tris-HCl, $\mathrm{pH} 7.5$, containing $0.1 \%$ vol/vol Triton X-100, $0.020 \mathrm{mM} \beta$ $\mathrm{NADH}$ and $0.100 \mathrm{mM} \mathrm{NBT}$ ) at $25^{\circ} \mathrm{C}$. Once the extract was added to the cuvette, the increase in absorbance at $525 \mathrm{~nm}$ was monitored by a Unikon 930 spectrophotometer and found to be linear for about $10 \mathrm{~min}$.

\section{Spectrophotometric characterisa-} tion of the nicotinamide adenine dinucleotide phosphate-diaphorase activity

To spectrophotometrically characterize NADPH-d activity, the standard reaction was carried out under the following modified conditions. To evaluate the spectral properties: the standard reaction for NADPH-d activity and the standard reaction mixture - with the omission of Triton X-100 or sample and $\beta$-NADH or sample and Triton X-100 - were analysed to the wavelength range 440 to $800 \mathrm{~nm}$. To evaluate the co-substrate affinity: $\beta$-NADPH was substituted for $\beta$-NADH. To evaluate the influence of the Triton X-100 concentration: the standard reaction was carried out in the presence of $0.1 \%, 0.3 \%, 1.0 \%, 2.0 \%, 2.5 \%, 5.0 \%$ or $10.0 \%$ Triton X-100. To evaluate the influence of $\mathrm{pH}$ : the standard reaction was carried out at $\mathrm{pH}$ $3.0,5.0,7.4,8.0$ or 10.0. To evaluate the influence of fixative solutions: T-samples were preincubated for $2 \mathrm{~h}$, at $2^{\circ} \mathrm{C}$, with a solution of 50 $\mathrm{mM}$ Tris-HCl (pH 7.4) and 1\%, 2\%, 4\%, 10\% PFA, $2 \%$ glutharaldeyde or $90 \%$ methanol $/ 3.7 \%$ phormaline. Afterwards, the samples were rinsed in $50 \mathrm{mM}$ Tris- $\mathrm{HCl}(\mathrm{pH} \mathrm{7.4)}$ and the TEsample processed for the standard NADPH-d reaction. To evaluate the influence of inhibitors: the standard spectrophotometric evaluation was carried out in the presence of one of the following compounds:

- $0.1 \mathrm{mM} N$-nitro-L-arginine-methylester (LNAME) - an analogous compound of arginine - inhibiting NO synthesis; ${ }^{49}$

$60 \mathrm{mM}$ pyruvate, a competitive inhibitor of mitochondrial respiratory enzymes; ${ }^{50}$

$0.5 \mathrm{mM}$ warfarin, an inhibitor of NADPHquinone oxidoreductase activity; 54

$0.1 \mathrm{mM}$ dichlorophenolindophenol (DPIP), an electron acceptor and bNOS competitor; 55 $5 \mathrm{mM}$ sodium azide, a competitive inhibitor of mitochondrial respiratory enzymes;

- $1 \mathrm{mM}$ 5,5'-Dithiobis(2-nitrobenzoic acid) (DTNB), a sulphydric inbitor. ${ }^{50}$

\section{Cellular localisation}

In order to evaluate the localisation of NADPH-d activity, the total protein content of TE-sample, ME-sample and C-sample, was quantified by using the BioRad Assay Kit (BioRad, Hercules, CA, USA), within factory specifications. NADPH-d activity itself was measured by the standard reaction for spectrophotometric evaluation of NADPH-d activity.

\section{Statistical analysis}

The experiments were carried out at least three times. The statistical analysis was performed using a two-way ANOVA test followed by the Student-Newman-Keuls multi-comparison test to discriminate statistically significant results (significance level: $\mathrm{P}<0.05$ ).

\section{Results}

\section{Detection of the nicotinamide adenine dinucleotide phosphate- diaphorase activity by non-denaturing electrophoresis}

The electrophoretic analysis carried out in the presence of the co-substrate $\beta$-NADPH (Figure $1 \mathrm{~A}$ ) or $\beta$-NADH (Figure $1 \mathrm{~B}$ ) showed the presence of the same band of apparent molecular mass of about $175 \mathrm{kDa}$. The OD measures obtained with Image J 1.33j software (NIH, Bethesda, MD, USA) revealed that the intensity of the diaphorase reaction depends on the co-substrate used. This is less evident in $\beta$-NADPH than in $\beta$-NADH.

\section{Detection of nitric oxide synthase- related molecules by immunoblot analysis}

In the immunoblot analysis, the anti-NOS antibodies did not recognise immunoreactive band in the samples of $D$. discoideum and a 
band in mouse brain homogenate (these data are not shown here).

\section{Histochemistry detection of the nicotinamide adenine dinucleotide phosphate-diaphorase activity}

The histochemistry analysis showed that diaphorase staining in the cytoplasm is more intense in the presence of $\beta$-NADH (Figure $2 \mathrm{~B}$ ) than in the presence of $\beta$-NADPH (Figure $2 \mathrm{C}$ ).

\section{Spectrophotometric detection of the nicotinamide adenine dinucleotide phosphate-diaphorase activity}

The spectrophotometric analysis carried out on T-sample showed that diaphorase activity is higher in the presence of co-substrate $\beta$-NADH (Figure $3 \mathrm{~B}$ ) than in the presence of $\beta$-NADPH (Figure $3 \mathrm{~A}$ ).

\section{Characterisation of the nicoti-} namide adenine dinucleotide phosphate-diaphorase activity by spectrophotometric analysis

The spectral analysis of NAD(P)H-d reaction showed a maximal absorbance value at $525 \mathrm{~nm}$ (Figure 4, corresponding symbol: circle). NAD(P)H-d activity had a wide range of tolerance to non-ionic detergent Triton X-100. When the reaction was carried out in the presence of $0.1 \%$ to $2 \%$ Triton $\mathrm{X}-100$, no significant variations were observed (Figures $5, \mathrm{~A}, \mathrm{~B}, \mathrm{C}, \mathrm{D}$, and E). On the contrary, 5\% Triton X-100 partially inhibited the activity (Figure $5 \mathrm{~F}$ ) and $10 \%$ Triton X-100 made it very low (Figure $5 \mathrm{G}$ ).

The increasing $\mathrm{pH}$ values exposure affected the intensity of $\mathrm{NAD}(\mathrm{P}) \mathrm{H}-\mathrm{d}$ reaction in a $\mathrm{pH}$ - dependent manner (Figure 6). The activity was highest at $\mathrm{pH} 8.0$ to10.0 (Figures $6 \mathrm{D}$ and $\mathrm{E}$ ) and lowest at $\mathrm{pH} 3.0$ (Figure $6 \mathrm{~A}$ ).

The pre-incubation of T-samples in solutions with fixatives also influenced the diaphorase activity (Figure 7). T-samples preincubated with $1 \%$ to $4 \%$ PFA showed some $25 \%$ decrease in the activity (Figures $7 \mathrm{~B}, \mathrm{C}$, and D), while T-samples pre-incubated with $10 \%$ PFA approximately decreased by $38 \%$ (Figure 7 E). Finally, exposition to methanol/formalin $(90 \% / 37 \%)$ or $2 \%$ glutaraldeyde decreased NADPH-d activity by about $38 \%$ (Figure $7 \mathrm{~F}$ ) and $73 \%$, respectively (Figure $7 \mathrm{G}$ )

The sensitivity of the T-samples to inhibitors of enzymes having NADPH-d activity is showed in Figure 8. In comparison with the control activity obtained with the standard NADPH-d reaction (Figure $8 \mathrm{~A}$ ), this activity was unaffected by exposure to $0.1 \mathrm{mM} \mathrm{L}$ NAME, $5.0 \mathrm{mM}$ sodium azide, $0.5 \mathrm{mM}$ warfarin (Figures $8 \mathrm{~B}, \mathrm{C}$, and D). The activity decreases significantly after exposure to $60.0 \mathrm{mM}$ pyruvate (Figure $8 \mathrm{E}$ ), $0.1 \mathrm{mM}$ DPIP (Figure $8 \mathrm{~F}$ ), and $1.0 \mathrm{mM}$ DTNB (Figure $8 \mathrm{G}$ ) (the power of inhibition was DPIP $>$ DTNB=pyruvate). Finally, as showed in Figure 9, TE-sample and C-sample had the same NAD(P)H-d activity.

\section{Discussion}

The presence of $\mathrm{NAD}(\mathrm{P}) \mathrm{H}-\mathrm{d}$ activity in $D$. discoideum cells has been identified first in this study. NAD(P)H-d activity shows different levels of co-substrate affinity, higher for $\beta$ $\mathrm{NADH}$ than for $\beta-\mathrm{NADPH}$, as is demonstrated by non-denaturing electrophoresis, histochemical and spectrophotometrical analyses. This enzyme activity is almost completely localised in the cytoplasmic fraction, which is in line with what Kuonen et al. ${ }^{53}$ observed in the rat brain for NOS-related NADPH-d reaction.

The spectral characterisation of the $\mathrm{NAD}(\mathrm{P}) \mathrm{H}-\mathrm{d}$ reaction using the co-substrate $\beta$ NADH reveals a maximal absorbance value at $525 \mathrm{~nm}$, which is similar to what observed in the case of NADPH-d activity in rat brain ${ }^{53}$ and opossum tissues, ${ }^{55}$ and with commerciallyavailable water-insoluble formazan. ${ }^{53,55}$ The

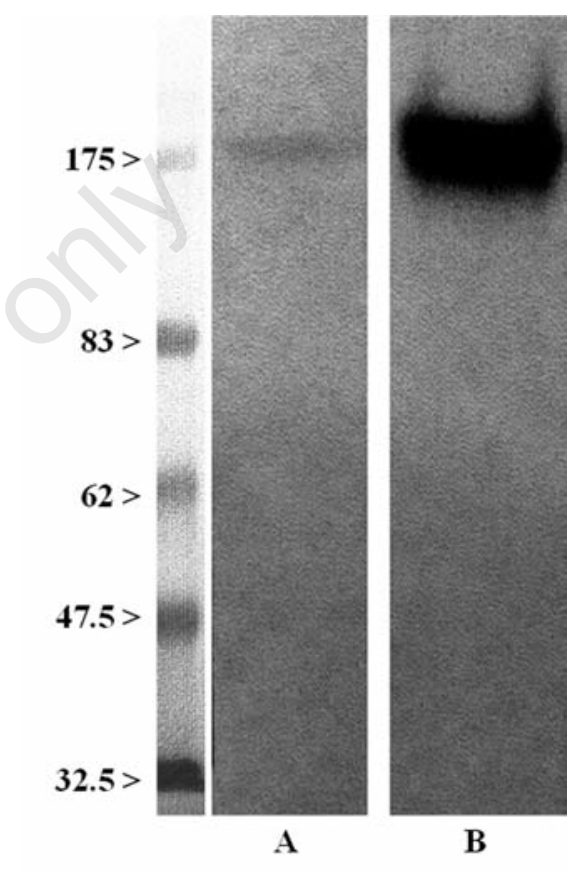

Figure 1. Pattern of NAD(P)H-d activity in $D$. discoideum by non-denaturing electrophoresis. The co-substrate used were $\beta$ NADPH (A) and $\beta-N A D H(B)$.
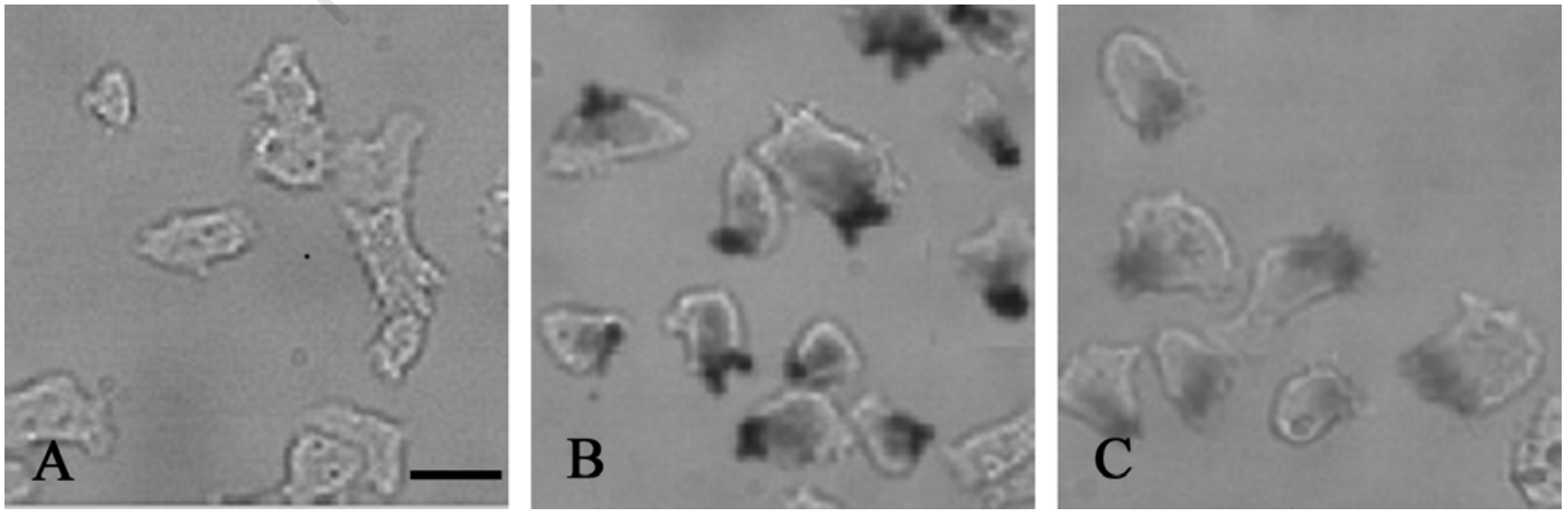

Figure 2. Histochemistry detection of $\mathrm{NAD}(\mathrm{P}) \mathrm{H}-\mathrm{d}$ activity. The reaction was carried out in the presence of co-substrates $\beta$-NADH $(\mathrm{B})$ and $\beta$-NADPH $(C)$ and in the absence of the co-substrate $(A)$. Scale bars $=10 \mu \mathrm{m}$. 
Dictyostelium's NAD(P)H-d reveals a different sensitivity to cell fixative, $\mathrm{pH}$ and Triton X-100 concentrations. Some fixatives, such as PFA and glutharaldeyde, are known to inhibit NADPH-d activity. ${ }^{56}$ However, as shown in the Helix pomatia nervous system, only the NOSunrelated NADPH-d reaction is completely suppressed, while NOS-related NADPH-d activity is not particularly sensitive. ${ }^{57}$ In addition, a solution of methanol/formalin in the nervous system of Periplaneta americana do not alter the NOS-related NADPH-d activity. In our study $\mathrm{NAD}(\mathrm{P}) \mathrm{H}-\mathrm{d}$ activity was inhibited by exposure to either PFA (1\% to $10 \%$ ) or methanol/formalin, but not in a dose-dependent manner and not drastically.

Exposure to different $\mathrm{pH}$ shows the sensitivity of the Dictyostelium NAD(P)H-d to acid $\mathrm{pH}$ and a higher activity in $\mathrm{pH} 8.0$ to 10.0 . This result is in line with the observations made by Kuonen et $a l^{53}$ on the characterisation of NADPH-d activity in the rat brain, but differ from Spessert and Claassen's results. ${ }^{49}$ These authors found high sensitivity to the NOSrelated NADPH-d in the rat olfactory bulb at basic $\mathrm{pH}$.

As demonstrated by Fang et al., 55 Triton X100 is able to improve NADPH-d reaction, probably by catalysing the activity of diaphorase, by keeping staining nitroblue diformazan in solution thus suppressing the straining of nonneuronal structure, and by increasing the permeability of the cell membrane. However, highly concentrated Triton X-100 is known to be a denaturing protein. In Dictyostelium cells, $\mathrm{NAD}(\mathrm{P}) \mathrm{H}-\mathrm{d}$ activity is not sensitive to $0.1 \%$ to $2.5 \%$ Triton X-100. Yet, it is inhibited by $5 \%$ Triton X-100 and is almost completely suppressed after exposure to $10 \%$ Triton X-100. This result conforms to the finding that NOSrelated NADPH-d activity is not particularly sensitive to low concentration of Triton X-100, while NOS-unrelated NADPH-d activity is inhibited by approximately $2 \%$ Triton $\mathrm{X}$ $100 . .^{49,53,55}$

Exposure to specific inhibitors of enzymes showing diaphorase activity further supports the hypothesis that the Dictyostelium NAD(P)H-d could be NOS-related. After incubation with DPIP - a NOS competitor $-^{49}$ the diaphorase activity is inhibited by about $50 \%$ compared to the control samples. A similar result has been found in Paramecium primaurelia, where NOS-related NADPH-d activity was inhibited by exposure to DPIP by about $50 \%{ }^{25}$

On the other hand, exposure to L-NAME an analogous compound of arginine and inhibitor of NO synthesis - is unaffected by the diaphorase activity. The $20 \%$ and $25 \%$ decrease in the activity caused by exposure to pyruvate and DTNB, respectively, also suggests the presence of some NOS-unrelated
NAD(P)H-d activity. The diaphorase reaction appears to be unaffected by exposure to sodium azide and warfarin. The findings of the non-denaturing electrophoretic analysis show the presence of one protein, which shows diaphorase activity, of apparent molecular mass of about $175 \mathrm{kDa}$ that oxidizes co-sub-

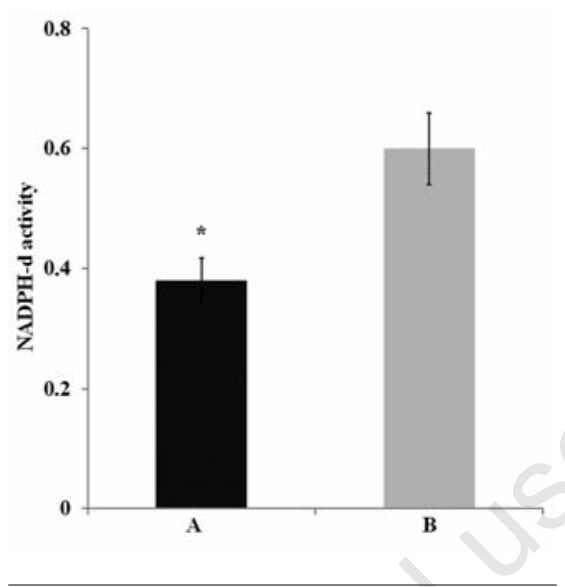

Figure 3. Spectrophotometric detection of NAD(P)H-d activity. The reaction was carried out in the presence of the $\beta-N A D P H$ (A) and $\beta-\mathrm{NADH}$ (B) co-substrates. NAD $(\mathrm{P}) \mathrm{H}$-d activity was expressed as $\Delta \mathrm{OD} / \mathrm{min} /$ total proteins. The symbol * indicates a significant difference $(\mathbf{P}<\mathbf{0 . 0 5})$ with regard to the reaction processed with the $\beta$-NADH (B) co-substrate.

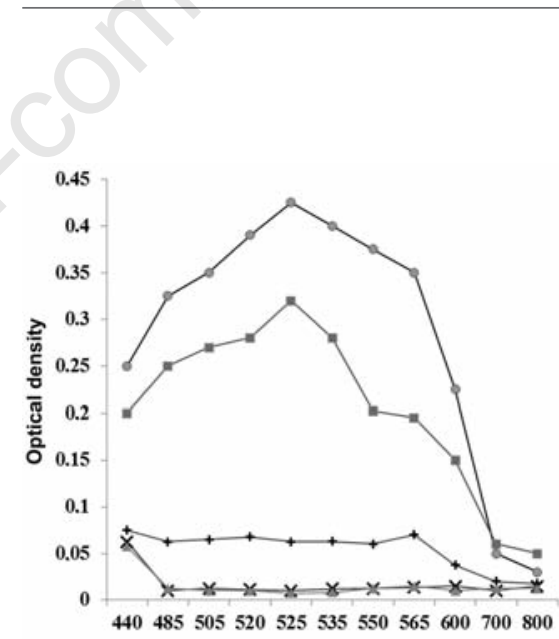

Figure 4. Spectral analysis of $\mathrm{NAD}(\mathrm{P}) \mathrm{H}-\mathrm{d}$ reaction and standard reaction mixture. Symbols are used as follows. Circle: standard reaction ( $\beta-\mathrm{NADH}$, Triton X-100, NBT and sample); square: reaction mixture ( $\beta$-NADH, NBT, sample); plus: reaction mixture $(\beta-N A D H$, Triton $\mathrm{X}-100, \mathrm{NBT})$; $X$ : reaction mixture $(\beta-N A D H, N B T)$; triangle: reaction mixture (Triton-X-100, NBT). strate $\beta$-NADH with higher affinity than $\beta$ NADPH. In previous papers we have shown that Enterobacter aerogenes can exhibit two NADPH-diaphorase activities with an apparent molecular mass of $124 \mathrm{kDa}$ and $47 \mathrm{kDa} .{ }^{25}$ For this reason, NADPH-d activity shown for $D$. discoideum is not a consequence of bacterial pol-

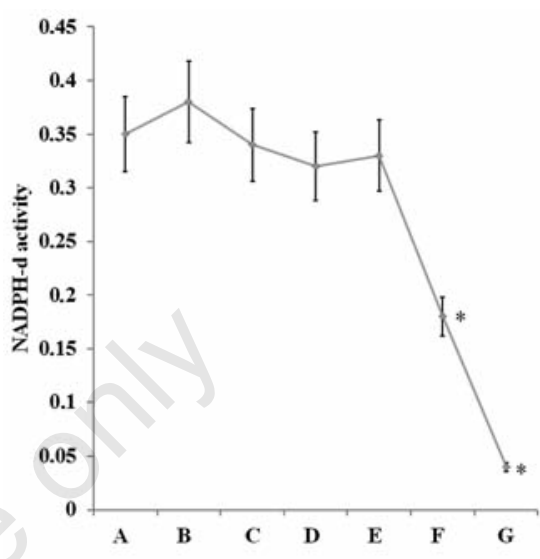

Figure 5. Spectrophotometric detection of the effect of Triton X-100 on NAD(P)H-d activity. The standard reaction was carried out in the presence of the following Triton X-100 concentrations: $\mathbf{0 . 1 \%}(\mathrm{A}), \mathbf{0 . 3 \%}(\mathrm{B})$, 1\% (C), 2\% (D), 2.5\% (E), 5\% (F), 10\% (G). The NAD(P)H-d activity was expressed as $\Delta O D / \mathrm{min} /$ total proteins. The symbol $*$ indicates the significant difference $(P<0.05)$ with regard to the reaction processed in the presence of $0.1 \%$ (A) Triton X-100.

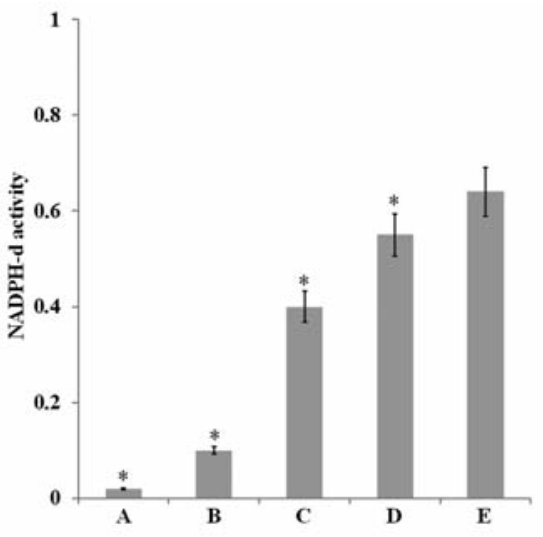

Figure 6. Spectrophotometric detection of the effect of $\mathrm{pH}$ on $\mathrm{NAD}(\mathrm{P}) \mathrm{H}-\mathrm{d}$ activity. The standard reaction was carried out at the following $\mathrm{pH}$ values: 3.0 (A), 5.0 (B), 7.4 (C), 8.0 (D), 10.0 (E). NAD(P)H-d activity was expressed as $\Delta O D / \mathrm{min} /$ total proteins. The symbol * indicates the significant difference $(P<0.05)$ with regard to the preceding $\mathrm{pH}$ value. 


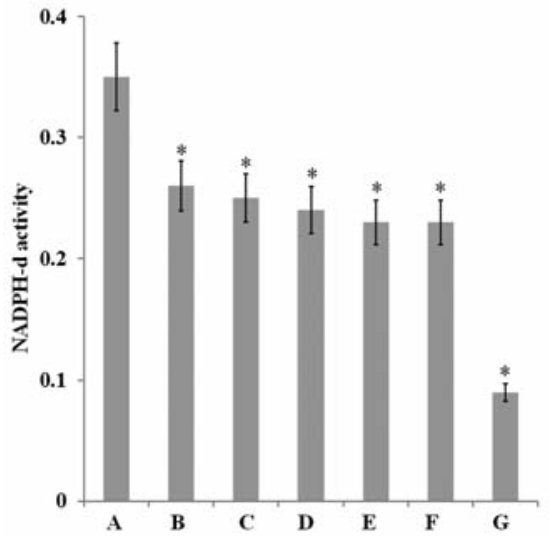

Figure 7. Spectrophotometric detection of the effect of cell fixative on $\mathrm{NAD}(\mathrm{P}) \mathrm{H}-\mathrm{d}$ activity. T-samples were pre-incubated with fixative and subsequently the standard reaction was performed. Control (A), 1\% paraphormaldeyde (PFA) (B), 2\% PFA (C), 4\% PFA (D), 10\% PFA (E), 90\% methanol/ $3.7 \%$ phormaline (F), $2 \%$ glutharaldeyde (G). NAD(P)H-d activity was expressed as $\triangle \mathrm{OD} / \mathrm{min} /$ total proteins. The symbol * indicates the significant difference $(P<0.05)$ with regard to the control (A).

lution by $E$. aerogenes. Lastly, the anti-NOS antibodies do not recognize NOS-related molecules in immunoblot analysis. In conclusion, it is important to point out that diaphorase activity shows how difficult it is to establish an experimental condition that clearly distinguish between NOS-related and -unrelated NADPH-d activity. The sensitivity of NOS-related NADPH-d to physical-chemical parameters changes between organisms and is tissue-specific. ${ }^{40,50,53,57-59}$ With regard to the NAD(P)H-d activity described in $D$. discoideum, however, there are numerous results which suggest its correlation to the presence of NOS enzyme, not least to the inhibition by DPIP. Insensitivity to the L-NAME inhibitor does not change this hypothesis for it is known that the reduction of the NBT substrate occurs without the conversion of L-arginine to citrulline and NO, according to the hypothesis that NO synthesis does not take place in fixed tissues. ${ }^{25,55}$ The effect observed after exposure to pyruvate or DTNB could indicate the presence of $\mathrm{NAD}(\mathrm{P}) \mathrm{H}-\mathrm{d}$ activity due to NOS-unrelated enzymes, such as lactate dehydrogenase, the enzyme described in Dictyostelium. ${ }^{60}$ However, the DTNB inhibition can be the consequence of its effect on the NOS after exposure to sulfhydryl inhibitors of the Mesocricetus auratus's NOS, as described by Wehby and Frank (1999). ${ }^{50}$ The non-denaturing electrophoresis analysis clearly shows that the $D$. discoideum's NAD(P)H-d
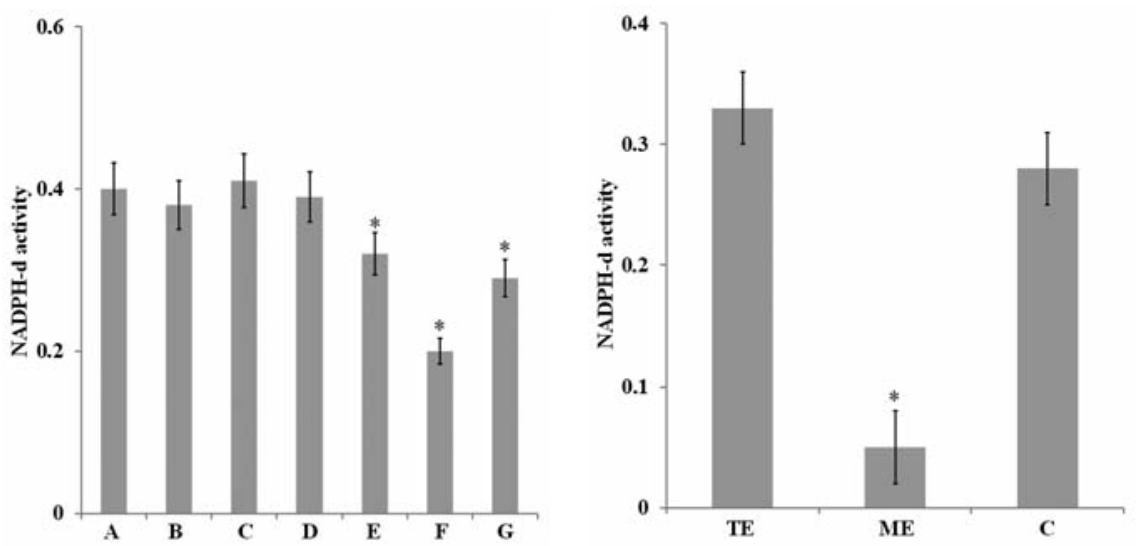

Figure 8. Spectrophotometric detection of the effect inhibitors on the $\mathrm{NAD}(\mathrm{P}) \mathrm{H}-\mathrm{d}$ activity. The standard reaction was carried out in the presence of the following inhibitors: 0.1 mM L-NAME (B), $5.0 \mathrm{mM}$ sodium azide $(\mathrm{C}), 0.5 \mathrm{mM}$ warfarin $(\mathrm{D}), 60$ mM pyruvate (E), $0.1 \mathrm{mM}$ DPIP (F), $1 \mathrm{mM}$ DTNB (G). The standard reaction carried out in the absence of inhibitors is considered as control (A). The NAD(P)H-d activity was expressed as $\triangle O D / \mathrm{min} /$ total proteins. The symbol ${ }^{*}$ indicates the significant difference $(P<0.05)$ with regard to the control (A).

is due to one protein of apparent molecular mass of $175 \mathrm{kDa}$. This is within the range of molecular masses indicated in literature for the NOS-related NADPH- $\mathrm{d}^{53}$ and is not representative of the molecular mass of the majority of proteins showing NADPH-d activity. Our results, like those indicating NO production in D. discoideum cells, ${ }^{48}$ provide further evidence of the presence of the NOS enzyme in Dictyostelium, an enzyme that does not show epitopes recognizable by the usual anti-NOS antibody.

\section{References}

1. McMahon D. Chemical messengers in development: a hypothesis. Science 1974; 185:1012-21.

2. Drews U. Cholinesterase in embryonic development. Prog Histochem Cyto 1975; 7:1-52.

3. Ozaki H. Molecular properties and differentiation of acetylcholinesterase in sea urchin embryos. Dev Growth Differ 1976; 18:245-57.

4. Nelson L. Chemistry and neurochemistry of sperm motility. Fed Proc 1978;37:2543-7.

5. Eusebi F, Pasetto N, Siracusa G. Acetylcholine receptor in human oocytes. $\mathrm{J}$
Figure 9. Spectrophotometric detection of the NAD $(\mathbf{P}) \mathrm{H}$-d localisation in $D$. disbrane-sample extract (ME), cytoplasmsample $(\mathrm{C})$. The $\mathrm{NAD}(\mathrm{P}) \mathrm{H}-\mathrm{d}$ activity was expressed as $\Delta O D / \mathrm{min} /$ total proteins. The symbol * indicates the significant difference $(P<0.05)$ with regard to the total sample extract (TE).

Physiol-London 1984;346:321-30.

6. Falugi C, Castellani P, Raffanti S, Borsi L, Zardi L. Acetylcholinesterase in normal and malignant human cells. Basic Appl Histochem 1986;30:433-46.

7. Falugi C, Borgiani L, Faraldi G, Tagliafierro G, Toso F, Drews U. Localisation and possible functions of neurotransmitter systems in sperms of different animal species, pp 475-9. In: B. Baccetti (ed.), Comparative spermatology, 20 years later. New York, USA, Raven Press, 1991.

8. Buznikov GA. Neurotransmitters in embryogenesis. Vol. 1. Chur, Switzerland, Harwood Academic Press, 1990.

9. Minganti A, Falugi C. An epithelial localization of acetylcholinesterase in the ascidian Cyona intestinalis embryos and larvae. Acta Embryol Morphol Exp 1980; 1:143-55.

10. Fluck RA, Shih TM. Acetylcholine in embryos of Oryzias latipes, a teleost: gas chromatographic-mass spectrometric assay. Comp Biochem Physiol 1981;70:12930.

11. Fluck RA. Localisation of acetylcholinesterase activity in young embryos of medaka Oryzias latipes, a teleost. Comp Biochem Physiol 1982;72:59-64.

12. Falugi C, Raineri M. Acetylcholinesterase (AChE) and pseudocholinesterase (BuChE) activity distribution pattern in coideum. Total sample extract (TE), mem- 
early developing chick limbs. J Embryol Exp Morph 1986;86:89-108.

13. Oettling G, Schmidt H, Drews U. The muscarinic receptor of chick embryo: correlation between ligand and calcium mobilization. J Cell Biol 1985;100:1073-81.

14. Laasberg T, Neuman T, Langel $U$. Acetylcholine receptors in the gastrulating chick embryo. Experientia 1986;42:439-49.

15. Laasberg T, Pedak A, Neuman T. The muscarinic receptor-mediated action of acetylcholine in the gastrulating chick embryo. Comp Biochem Physiol 1987;86:313-6.

16. Talesa V, Principato GB, Mangiabene C, Giovannini E, Norton SJ, Rosi G. Cholinesterasi in the cnidarians Velella velella (Hydrozoa: Syphonophora) and Actinia equina (Anthozoa: Actimaria): a comparative study. J Exp Zool 1992;263:367-73.

17. Jaffe MJ. Evidence for the regulation of phytocrome mediated processes in bean roots by the neurohumor, acetylcholine. Plant Physiol 1970;46:768-77.

18. Fluck RA, Jaffe MJ. Cholinesterases from plant tissues. Biochim Biophys Acta 1975; 410:130-4.

19. Basu NK, Kole L, Ghosh A, Das PK. Isolation of a nitric oxide synthase from the protozoan parasite, Leishmania donovani. Fems Microbiol Lett 1997;156:43-7.

20. Delmonte Corrado MU, Politi H, Trielli F, Angelini C, Falugi C. Evidence for the presence of a mammalian-like cholinesterase in Paramecium primaurelia (Protista ciliophora) developmental cycle. J Exp Zool 1999;283:102-5.

21. Goldstein J, Paveto C, López-Costa JJ, Pereira C, Alonso G, Torres HN, et al. Immuno and cytochemical localization of Trypanosoma cruzi nitric oxide synthase. Biocell 2000;24:217-22.

22. Golderer G, Werner ER, Leitner S, Gröbner P, Werner-Felmayer G. Nitric oxide synthase is induced in sporulation of Physarum polycephalum. Gene Dev 2001;15:1299-309.

23. Falugi C, Amaroli A, Evangelisti V, Viarengo A, Delmonte Corrado MU. Cholinesterase activity and effects of its inhibition by neurotoxic drugs in Dictyostelium discoideum. Chemosphere 2002;48:407-14.

24. Amaroli A, Gallus L, Passalacqua M, Falugi C, Viarengo A, Delmonte Corrado MU. Detection of cholinesterase activities throughout the developmental cycle of Dictyostelium discoideum. Eur J Protistol 2003;39:213-22.

25. Amaroli A, Ognibene M, Trielli F, Trombino S, Falugi C, Delmonte Corrado MU. Detection of NADPH-diaphorase activity in Paramecium primaurelia. Eur J Protistol 2006;42:201-8.
26. Amaroli A, Trielli F, Sifredi F, Chessa MG, Delmonte Corrado MU. Nitric oxide production is inhibited by xenobiotic compounds in the protozoan Paramecium primaurelia. Ecol Indic 2010;10:212-6.

27. Amaroli A. The effect of pesticides on Dictyostelium discoideum cholinesterase, from basic to applied research, pp 279-94. In: M. Stoytcheva (ed.), Pesticides in the modern world. Rejeka, Croazia, InTech Publishers, 2011.

28. Ramoino P, Milanese M, Candiani S, Diaspro A, Fato M, Usai C, et al. Gammaamino butyric acid (GABA) release in the ciliated protozoon Paramecium occurs by neuronal-like exocytosis. J Exp Biol 2010; 213:1251-8.

29. Bucci G, Ramoino P, Diaspro A, Usai C. A role for GABAA receptors in the modulation of Paramecium swimming behavior. Neurosci Lett 2005;386:179-83.

30. Anjard C, Loomis WF. GABA induces terminal differentiation of Dictyostelium through a GABAB receptor. Development 2006;133:2253-61.

31. Trielli F, Amaroli A, Sifredi F, Marchi B, Falugi C, Delmonte Corrado M.U. Effects of xenobiotic compounds on the cell activities of Euplotes crassus, a single-cell eukaryotic test organism for the study of the pollution of marine sediments. Aquat Toxicol 2007;83:272-83.

32. Yun HY, Dawson VL, Dawson TM. Neurobiology of nitric oxide. Crit Rev Neurobiol 1996;10:291-316.

33. Alderton WK, Cooper CE, Knowles RG. Nitric oxide synthases: structure, function and inhibition. Biochem J 2001;357:593615.

34. Marletta MA. Nitric oxide synthase structure and mechanism. J Biol Chem 1993;268:12231-4.

35. Dawson TM, Bredt DS, Fotuhi M, Hwang PM, Snyder SH. Nitric oxide synthase and neuronal NADPH diaphorase are identical in brain and peripheral tissues. P Natl Acad Sci USA 1991;88:7797-801.

36. Hope BT, Michael GJ, Knigge KM, Vincent SR. Neuronal NADPH diaphorase is a nitric oxide synthase. P Natl Acad Sci USA 1991;88:2811-4.

37. Young HM, Furness JB, Shuttleworth CWR, Bredt DS, Snyder SH. Co-localisation of nitric oxide synthase immunoreactivity and NADPH diaphorase staining in neurons of guinea-pig intestine. Histochemistry 1992;97:375-8.

38. Stoward PJ, Meijer AEFH, Seidler E, Wohlrab F. Dehydrogenase, pp 27-71. In: P.J. Stoward, A.G.E. Pearse (eds.), Histochemistry: theoretical and applied. Enzyme histochemistry. Edinburgh, UK, Churchill Livingstone Publ., 1991.
39. Ward SM, Xue C, Shuttleworth CWR, Bredt SD, Snyder SH, Sanders KM. NADPH diaphorase and nitric oxide synthase colocalization in enteric neurons of canine proximal colon. Am J Physiol 1992;263: 277-84.

40. Matsumoto T, Nakane M, Pollock JS, Kuk JE, Forstermann UA. A correlation between soluble brain nitric oxide synthase and NADPH-diaphorase activity is noly seen after exposure of the tissue to fixative. Neurosci Lett 1993;155:61-4.

41. Tracey WR, Nakane M, Pollock JS, Forstermann U. Nitric oxide synthases in neuronal cells, macrophages and endothelium are NADPH-diaphorase, but represent only a fraction of total cellular NADPH diaphorase activity. Biochem Bioph Res Co 1993;195:1035-40.

42. Malvin GM, Cecava N, Nelin LD. Nitric oxide production and thermoregulation in Paramecium caudatum. Acta Protozool 2003;42:259-67.

43. Tao Y, Howlett A, Klein C. Nitric oxidereleasing compounds inhibit Dictyostelium discoideum aggregation without altering cGMP production. Febs Lett 1992;314:4952.

44. Tao Y, Howlett A, Klein C. Nitric oxide inhibits the initiation of cAMP pulsing in D. discoideum without altering receptoractivated adenylate cyclase. Cell Signal 1996;8:26-34.

45. Tao Y, Howlett A, Klein C. Nitric oxide stimulates the ADP-ribosylation of a 41$\mathrm{kDa}$ cytosolic protein in Dictyostelium discoideum. P Natl Acad Sci USA 1992;89: 5902-6.

46. Tao Y, Howlett AC, Klein C. Endogenous ADP-ribosylation of glyceraldehyde-3phosphate dehydrogenase that is not regulated by nitric oxide in Dictyostelium discoideum. Cell Signal 1993;5:763-75.

47. Tao Y, Howlett A, Klein C. Nitric oxide regulation of glyceraldehyde-3-phosphate dehydrogenase activity in Dictyostelium discoideum cells and lysates. Eur J Biochem 1994;224:447-54.

48. Tao YP, Misko TP, Howlett AC, Klein C. Nitric oxide, an endogenous regulator of Dictyostelium discoideum differentiation. Development 1997;124:3587-95.

49. Spessert R, Claassen M. Histochemical differentiation between nitric oxide synthase-related and -unrelated diaphorase activity in the rat olfactory bulb. Histochem J 1998;30:41-50.

50. Wehby RG, Frank ME. NOS- and non-NOS NADPH diaphorase in the insular cortex of the Syrian golden hamster. J Histochem Cytochem 1999;47:197-207.

51. Amaroli A, Trielli F, Bianco B, Giordano S, Moggia E, Delmonte Corrado MU. Effects 
of $50 \mathrm{~Hz}$ magnetic field on Dictyostelium discoideum (Protista). Bioelectromagnetics 2006;27:528-34.

52. Swan P, Garrod DR, Morris D. An inhibitor of cell cohesion from axenically grown cells of the slime mould Dictyostelium discoideum. J Cell Sci 1997;28:107-16.

53. Kuonen DR, Kemp MC, Roberts PJ. Demonstration and biochemical characterization of rat brain NADPH-dependent diaphorase. J Neurochem 1988;50:1017-25.

54. Preusch PC, Suttie JW. Vitamin K-dependent reactions in rat liver: role of flavoproteins. J Nutr 1981;111:2087-97.

55. Fang S, Christensen J, Conklin JL, Murray JA, Clark G. Role of Triton X-100 in NADPH-diaphorase histochemistry. J
Histochem Cytochem 1994;42:1519-24.

56. Spessert R, Layes E. Fixation conditions affect the intensity but not the pattern of NADPH-diaphorase staining as a marker for neuronal nitric oxide in rat olfactory bulb. J Histochem Cytochem 1994;42:130915.

57. Huang S, Kerschbaum HH, Engel E, Hermann A. Biochemical characterization and histochemical localization of nitric oxide synthase in the nervous system of snail, Helix pomatia. J Neurochem 1997; 69:2516-28.

58. Spessert R, Wohlgemuth C, Reuss S, Layes E. NADPH-diaphorase activity of nitric oxide synthase in the olfactory bulb: cofactor specificity and characterization regarding the interrelation to NO formation. J Histochem Cytochem 1994;42:56975.

59. Grozdanovic Z, Baumgarten G, Bruning G. Histochemistry of NADPH-diaphorase, a marker for neuronal nitric oxide synthase, in the peripheral autonomic nervous system of the mouse. Neuroscience 1992;48: 225-35.

60. Schachner E, Aschhoff HJ, Kersten H. Specific changes in lactate levels, lactate dehydrogenase patterns and cytochrome b559 in Dictyostelium discoideum caused by queuine. Eur J Biochem 1984;139:481-7. 